\title{
Peranan Guru Dalam Membina Sikap dan Kedisiplinan Siswa Melalui Pendekatan Keteladanan Guru di SMP Negeri 2 Donggo
}

\author{
Achmad Djunaidi ${ }^{1}$, Titin Sarimawati $^{2}$
}

1Pendidikan Pancasila dan Kewarganegaraan, Universitas Muhammadiyah Mataram, Email: djuanidiachmad@gmail.com

2Pendidikan Pancasila dan Kewarganegaraan Universitas Muhammadiyah Mataram Email: titisarimawati996@gmail.com

\begin{tabular}{l} 
INFO ARTIKEL \\
Riwayat Artikel: \\
Diterima: $\quad$ 16-Agustus- \\
2019 \\
Disetujui: $25-S e p t e m b e r-$ \\
2019 \\
\hline
\end{tabular}

Kata Kunci:

Membina

Sikap

Kedisplinan

Keteladanan

\section{A. LATAR BELAKANG}

Pergaulan di masyarakat telah bergeser dari masyarakat yang menekankan rasa sosial telah berubah menjadi asosial. Hal itu disebabkan banyaknya pengaruh nilai-nilai asing yang masuk ke wilayah Indonesia tanpa melalui proses filterisasi. Pengaruh tersebut apabila dibiarkan tentu akan merusak akhlak dan moral generasi muda, khususnya siswa[1].

\begin{abstract}
Abstrak: Sikap siswa berperan sebagai penunjang dalam mencapai suatu tujuan pembelajaran. Sikap dipengaruhi perasaan pendukung atau tidak mendukung terhadap suatu objek. Terdapat banyak asumsi bahwa ada hubungan yang positif antara sikap siswa dengan hasil belajarnya. Tujuan penelitian ini untuk menjelaskan pernanan guru dalam membina sikap dan kedisplinan siswa melalui pendekatan keteladanan guru. Metode penelitian ini mneggunakan penelitian kualitatif dengan pendekatan deskriptif. Informan dalam penelitian ini adalah guru PPKn dan siswa di SMPN 2 Donggo. Pengumpulan data yang digunakan adalah observasi, interview dan dokumentasi. Analisis data menggunakan reduksi data, penyajian data verifikasi dan penarikan kesimpulan. Hasil penelitian menunjukkan bahwa 1) Peranan Guru dalam pembinaan disiplin siswa adalah meningkatkan ketaqwaan siswa, mengadakan pembinaan untuk mempertinggi budi pekerti dan kepribadian siswa; membimbing tingkah laku siswa sehari-hari di sekolah; 2) Bentuk pembinaan disiplin siswa yang dilakukan oleh guru adalah menunjukan/memberi contoh sikap disiplin; menegur siswa yang melanggar secara lisan; menyampaikan manfaat dari berdisiplin; memberikan sanksi terhadap siswa yang melanggar baik sanksi ringan maupun sanksi berat; 3) Faktor pendukung dalam memberikan keteladanan dan kedisiplinan guru PPKn siswa adalah suasana lingkungan belajar yang kondusif/nyaman, sarana pembelajaran yang memadai/ menunjang, dan peran serta orang tua dalam pendidikan anak.
\end{abstract}

\begin{abstract}
Students 'attitudes serve as supporting in achieving a learning objective. Beliefs influenced by feelings of support or not supporting an object. There are many assumptions that there is a positive relationship between students 'attitudes and their learning outcomes. The purpose of this research is to explain the teacher's attention to cultivating the philosophy and discipline of the students through the teacher's example. This method of study used qualitative research with a descriptive approach. The informant is the teacher of PPKn and students at SMPN 2 Donggo. The data collection used is observation, interview, and documentation. Data analysis used data reduction, presentation of verification data, and withdrawal of conclusions. The results showed that 1) the teacher's role in the coaching of students 'discipline is to increase the student's steady lit, conduct coaching to heighten the character's ethics and personality; Guiding the conduct of every day students at school; 2) The form of student discipline coaching conducted by the teacher is to demonstrate/give examples of disciplinary attitude; Rebuke the student who violates orally; Convey the benefits of disciplined; Sanctions on students who violate either mild or severe sanctions; 3) supporting factors in providing the teacher's transparency and discipline for students is a conducive/comfortable learning environment, adequate learning facilities, and parents ' participation in children's education.
\end{abstract}

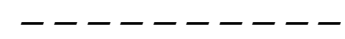

Sikap siswa berperan sebagai penunjang dalam mencapai suatu tujuan pembelajaran. Sikap dipengaruhi perasaan pendukung atau tidak mendukung terhadap suatu objek. Terdapat banyak asumsi bahwa ada hubungan yang positif antara sikap siswa dengan hasil belajarnya. Dengan kata lain, bahwa siswa yang mempunyai sikap positif terhadap pelajaran tertentu cenderung lebih tekun dalam belajar sehingga mencapai hasil yang memuaskan. Dan sebaliknya, siswa yang mempunyai sikap negatif terhadap pelajaran, dia tidak 
akan bersemangat belajar sehingga hasilnya kurang memuaskan[2].

Setiap siswa dituntut dan diharapkan untuk berperilaku setuju dengan aturan dan tata tertib yang berlaku di sekolahnya. Perilaku, aturan dan tata tertib yang berlaku di sekolah tersebut dapat dikelompokkan menjadi dua, yaitu: 1) Kepatuhaan dan ketaatan siswa terhadap berbagai peraturan dan tat tertib yang berlaku disekolahnya, itu biasa disebut dengan disiplin siswa. 2) Peraturan, tata tertib dan berbagai ketentuan lainya yang berupaya mengatur perilaku siswa disebut disiplin sekolah[3]. Sementara untuk indikator kedisplinan yaitu pelaksanaan disiplin siswa dalam kerapian, pelaksananaan disiplin siswa dalam kerajinan, dan pelaksanaan disiplin siswa dalam pengaturan waktu belajar[4]. Jadi tuntutan sikap dan kedisiplinan siswa menjadi modal utama bagi lembaga pendidik untuk menjadi layanan pendidikan yang kompeten.

Peranan guru PPKn sangat penting, selain memberi materi pelajaran guru PPKn pun berperan dalam membina kedisiplinan yang ada dalam diri siswanya seperti disiplin waktu, disiplin berpakaian dan berperilaku disiplin yang berbasiskan nilai moral. Menurut Badan Standar Nasional Pendidikan (BSNP) Tujuan Pendidikan Kewarganegaraan adalah agar peserta didik memiliki kemampuan sebagai berikut: 1) berpikir secara kritis, rasional, dan kreatif dalam menanggapi isu kewarganegaraan; 2) berpartisipasi secara aktif dan bertanggung jawab, dan bertindak secara cerdas dalam kegiatan bermasyarakat, berbangsa dan bernegara.

Berdasarkan tujuan PPKn di atas peran guru PPKn yaitu harus mampu membawa anak didiknya menjadi manusia Indonesia yang memiliki rasa kesadaran yang tinggi dalam melaksanakan tugas dan tanggung jawabnya sebagai warga negara yang baik. Proses pendidikan dapat berhasil, apabila adanya upaya penciptaan suasana belajar mengajar yang kondusif, dimana didalamnya harus tertanam perilaku disiplin yang baik, untuk itu diperlukan peran dan figur seorang guru yang bias bertanggung jawab dalam mengajar di sekolah dengan membina dan menjadi teladan bagi siswanya khususnya dalam hal kedisiplinan. Tenaga kependidikan sebagai pendidik bertanggung jawab untuk mewariskan nilai-nilai dan norma-norma kepada generasi berikutnya sehingga terjadi proses konservasi nilai dan terciptanya nilai-nilai yang baru[5].

Dapat dikatakan bahwa tenaga kependidikan yang tidak lain yaitu guru yang harus mempunyai rasa tanggung jawab untuk mewariskan nilai dan norma kepada siswanya melalui proses pendidikan karena dengan proses pendidikan dapat menciptakan nilai-nilai yang baru sehingga mampu merubah sikap siswa ke arah yang lebih baik. Setiap tanggung jawab memerlukan sejumlah kompetensi dan setiap kompetensi dapat diartikan lagi ke dalam kompetensi yang lebih khusus seperti: tanggung jawab moral, tanggungjawab tenaga kependidikan dalam bidang kemasyarakatan, dan tanggung jawab kependidikan dalam bidang keilmuan.

Guru PPKn harus banyak berusaha agar siswasiswinya mempunyai sikap yang baik, kecerdasan yang tinggi, serta keterampilan yang bermanfaat, oleh karena itu guru PPKn harus dapat memanfaatkan fungsinya sebagai penuntun moral, sikap, serta memberi dorongan ke arah yang lebih baik melalui pendekatan keteladanan guru[6].

Disiplin sebagai kondisi yang tercipta dan terbentuk melalui proses dari serangkaian perilaku yang menunjukkan nilai-nilai ketaatan, kepatuhan, kesetiaan, keteraturan atau ketertiban. Nilai-nilai tersebut telah menjadi bagian perilaku dalam kehidupannya. Perilaku itu tercipta melalui proses binaan melalui keluarga, pendidikan dan pengalaman.

"Disiplin merupakan sesuatu yang menyatu di dalam diri seseorang. Bahkan, disiplin itu sesuatu yang menjadi bagian dalam hidup seseorang, yang muncul dalam pola tingkah lakunya sehari-hari. Disiplin terjadi dan terbentuk sebagai hasil dan dampak proses pembinaan cukup panjang yang dilakukan sejak dari dalam keluarga dan berlanjut dalam pendidikan di sekolah. Keluarga dan sekolah menjadi tempat penting bagi pengembangan disiplin seseorang".

Pendapat lainnya menjelaskan pembentukan disiplin, terjadi karena disiplin akan tumbuh dan dapat dibina, melalui latihan, pendidikan, penanaman kebiasaan dan keteladanan[7]. Pembinaan itu dimulai dari lingkungan keluarga sejak kanak-kanak. Disiplin juga diproses melalui pembinaan sejak dini, sajak usia muda, dimulai dari keluarga dan pendidikan. Jadi pembentukan disiplin ternyata harus melalui proses panjang, dimulai sejak dini dalam keluarga dilanjutkan sekolah. Hal-hal penting dalam pembentukan itu terdiri dari kesadaran diri, kepatuhan, tekanan, sanksi teladan, lingkungan disiplin dan latihan-latihan.

PPKn merupakan program pendidikan yang memiliki misi untuk mengembangkan nilai luhur dari moral yang berakar pada budaya dan keyakinan bangsa Indonesia yang memungkinkan dapat diwujudkan dalam perilaku dalam kehidupan sehari-hari. Bagi guru SMP maupun pendidik di jenjang lainnya PPKn memiliki dua sisi kegunaan, Pertama untuk dirinya sendiri sebagai warga negara diharapkan menjadi sarana pemahaman, penghayatan, dan perwujudan nilai dan moral Pancasila dan UUD 1945 dalam kehidupan sehari-hari. Kedua, sebagai guru/pendidik diharapkan menjadi media pendidikan yang memungkinkan peserta didik secara sadar dan sistematis berupaya untuk mengerti, menghayati dan menerapkan nilai dan moral Pancasila dan UUD 1945 sesuai dengan perkembangan pribadi dan lingkungannya[8].

Peran guru PPKn dalam membentuk sikap dan kepribadian siswa yaitu membentuk sikap siswa yang mempertahankan hak dan kewajibannya serta mampu 
melaksanakan hak dan kewajibannya dengan baik. Membentuk siswa yang memiliki rasa cinta terhadap tanah air serta memiliki rasa kebangsaan yang kuat dan dapat membentuk siswa yang dapat menghormati orang dalam kehidupan di sekolah maupun di masyarakat serta mentaati aturan yang berlaku. Membentuk siswa yang dapat melaksanakan musyawarah dalam mengambil keputusan baik di sekolah maupun di masyarakat serta membentuk siswa yang mengakui bahwa indonesia ini adalah negara yang plural yaitu terdiri dari berbagai macam agama, suku, bahasa, dan budaya[9].

Pembinaan disiplin di SMP Negeri 2 Donggo sangat penting. Guru bisa memberikan pembinaan disiplin siswanya melalui keteladanan. Guru sendiri harus menjadi teladan dan memberikan contoh yang baik kepada siswanya. Keteladanan bisa dilakukan melalui ekstrakulikuler. Apabila ada siswa yang terlambat mereka harus diberi sanksi, atau peringatan agar tidak di ulangi lagi, dan siswa bisa mengetahui apa arti dari kedisiplinan dan keteladanan.

\section{B. METODE PENELITIAN}

\section{Pendekatan Penelitian}

Metode yang digunakan dalam penelitian ini adalah kualitatif. Definisi penelitian kualitatif penelitian kualitatif ini sering disebut metode penelitian naturalistik karena penelitiannya dilakukan pada kondisi yang alamiah (natural setting)[10], disebut juga sebagai metode etnografi karena pada awalnya, metode ini lebih banyak digunakan untuk penelitian bidang antropologi budaya, dan disebut sebagai metode kualitatif karena data yang terkumpul dan analisis lebih bersifat kualitatif atau dengan kata lain metode kualitatif adalah metode penelitian yang digunakan untuk meneliti kondisi objek yang ilmiah (lawanya adalah eksperimen) dimana penelitian merupakan instrument kunci, teknik pengumpulan data dilakukan secara triangulasi (gabungan), analisis data bersifat induktif, dan hasil penelitian kualitatif lebih menekan makna dari pada generalisasinya.

Penelitian kualitatif, objek yang alamiah, atau natural setting sehingga metode penelitian ini sering disebut sebagai metode naturalistik, objek yang alamiah adalah objek yang apa adanya, tidak dimanipulasi oleh peneliti pada saat peneliti memasuki objek, setelah berada di objek, dan setelah keluar dari objek relatif tidak berubah[11].

Metode deskriptif kualitatif adalah suatu metode dalam meneliti status kelompok manusia, suatu objek dengan tujuan membuat deskriptif, gambaran atau tulisan secara sistematis faktual dan aktual mengenai fakta-fakta atau fenomena yang terjadi. Dalam penelitian ini peneliti mendeskripsikan secara kualitatif Peranan Guru PPKn Dalam Membina Sikap dan Kedisiplinan Siswa Di Sekolah Melalui Pendekatan Keteladanan Guru Di SMP Negeri 2 Donggo.

\section{Subyek Penelitian}

Subyek penelitian adalah orang yang memberikan informasi tentang situasi dan kondisi tempat penelitian[12]. Pengambilan informan dilakukan secara purvosive sampling yakni yang menjadi informan sudah ditentukan sebelumnya berdasarkan tujuan penelitian[13]. Selain menggunakan purposive sampling, peneliti juga menggunakan teknik Snowball Sampling yakni teknik pengambilan sampel dimana sumber data yang pada awalnya jumlahnya sedikit, lama-lama menjadi besar. Dalam teknik snowball sampling, Informan penelitian yang pertama setelah diwawancara kemudian memberikan rekomendasi kepada peneliti terhadap informan berikutnya yang mengetahui persis tentang pergeseran nilai sosial budaya. Begitu juga dengan informan kedua, informan kedua juga memberikan rekomendasi kepada peneliti terhadap siapa yang diwawancara oleh peneliti. Begitu selanjutnya sampai pada keterangan-keterangan yang diporeleh sama, maka data yang terkumpul sudah dirasakan cukup dan tidak perlu menambah informan lagi karena informasi yang didapat dari para informan sudah sama.

Dari penjelasan mengenai kedua sampel di atas peneliti dapat menyimpulkan bahwa pada purposive sampling dengan kalimat pertimbangan tertentu, maksudnya orang tersebut yang dianggap paling tahu tentang apa yang diharapkan atau dia sebagai penguasa dengan kata lain guru atau kepala sekolah sehingga akan memudahkan peneliti menjelajahi objek/situasi sosial yang diteliti. Sedangkan pada snowball sampling hal ini dilakukan karena dari jumlah sumber data yang sedikit itu belum mampu memberikan data yang memuaskan, maka mencari orang lain lagi yang dapat digunakan sebagai sumber data, maksudnya apabila sumber data dari kepala sekolah tidak memuaskan, maka mencari guru-guru lain yang dapat digunakan sebagai sumber data..

\section{Teknik Pengumpulan Data}

Adapun teknik yang digunakan dalam mengumpulkan data lapangan adalah:

a. Observasi

Observasi adalah dasar semua ilmu pengetahuan, para ilmuan hanya dapat bekerja berdasarkan data, yaitu fakta mengenai dunia kenyataan yang diperoleh melalui observasi menurut Nasution dalam [14]. Teknik ini dilakukan untuk membuktikan kebenaran data atau informasi yang diperoleh melalui teknik wawancara. Pengumpulan data dengan teknik ini dimaksudkan untuk mengantisipasi kekurangan-kekurangan yang ada atau tidak dapat diungkapkan dalam wawancara. Observasi yang peneliti lakukan ialah observasi lansung dan tidak lansung.

\section{b. Interview (wawancara)}

Wawancara adalah percakapan dengan maksud tertentu oleh dua pihak, yaitu pewawancara (interviewer) sebagai pemberi pertanyaan dan yang diwawancarai 
(interviewer) sebagai pemberi jawaban atas pertanyaan itu[12]. Peneliti menggunakan metode wawancara untuk mendapatkan gambaran tentangperan guru daam membina sikap dan kedisplinan.

Wawancara peneliti lakukan dengan teknik terstruktur. Wawancara terstruktur adalah wawancara yang dilakukan dengan mengajukan beberapa pertanyaan yang diajukan dan telah disusun sebelumnya.Wawancara tidak terstuktur adalah wawancara dengan mengajukan beberapa pertanyaan secara lebih leluasa tanpa terkait oleh susunan pertanyaan yang telah dipersiapkan sebelumnya, biasanya pertanyaan muncul secara spontan sesuai dengan perkembangan situasi dan kondisi ketika melakukan wawancara, dalam wawancara peneliti memanfaatkan tipe recorder untuk merekam hasil wawancara dengan informan. Pertimbangan peneliti menggunakan tipe recorder ini adalah semata-mata agar proses pengambilan data lebih efektif dan efisien pada saat berada di lapangan. Peneliti melakukan wawancara terhadap tokoh masyarakat, tokoh agama dan tokoh adat dengan mengajukan beberapa pertanyaan kemudian direkam. Di akhir wawancara, hasil rekaman ini kemudian peneliti tulis kembali dalam buku catatan hasil penelitian.

\section{c. Dokumentasi}

Tehnik dokumentasi adalah suatu cara pengumpulan data yang menghasilkan catatan-catatan penting yang berhubungan dengan masalah yang diteliti, sehingga diperoleh data yang lengkap, bukan berdasarkan perkiraan. Metode ini hanya mengambil data yang sudah ada seperti indeks prestasi, jumlah anak, pendapatan, luas tanah, jumlah penduduk, dan sebagainya[12].

\section{Tehnik Analisis Data}

Teknik analisis data kualitatif adalah bersifat induktif, yaitu suatu analisis berdasarkan data yang diperoleh, selanjutnya dikembangkan menjadi hipotesis. Berdasarkan hipotesis yang dirumuskan berdasarkan data tersebut, dapat disimpulkan apakah hipotesis tersebut diterima atau ditolak berdasarkan data yang terkumpul. Bila berdasarkan data yang dapat dikumpulkan secara berulang-ulang dengan teknik triangulasi, ternyata hipotesis diterima maka hipotesis tersebut berkembang menjadi teori. Analisis data yang digunakan dalam penelitian ini yaitu analisis deskriptif kualitatif dengan menggunakan analisis model interaktif. Analisis interaktif terdiri dari tiga alur kegiatan yang terjadi secara bersama yaitu reduksi data, penyajian data dan penarikan kesimpulan, verifikasi[15].

1. Reduksi Data

Reduksi data diartikan sebagai pemilihan, pemusatan pada penyederhanaan, pengabstrakan dan transformasi data kasar yang muncul dari catatan-catatan tertulis dilapangan. Data yang direduksi dalam penelitian ini adalah data tentang Peranan Guru PPKn Dalam Membina Sikap dan Kedisiplinan Siswa Di Sekolah Melalui Pendekatan Keteladanan Guru Di SMP Negeri 2 Donggo.

\section{Penyajian Data}

Alur penting yang kedua dari kegiatan analisis data adalah penyajian data sebagai kesimpulan informasi tersusun yang memberikan kemungkinan adanya penarikan kesimpulan dan pengambilan tindakan. Data yang disajikan dalam penelitian ini mengenai Peranan Guru PPKn Dalam Membina Sikap dan Kedisiplinan Siswa Di Sekolah Melalui Pendekatan Keteladanan Guru Di SMP Negeri 2 Donggo.

\section{Menarik Kesimpulan}

Penarikan kesimpulan hanyalah sebagai suatu bagian konfigurasi yang utuh, kesimpulan-kesimpulan juga diverivikasi selama penelitian berlangsung. Analisis data dalam penelitian ini dilakukan setelah data terkumpul dan diseleksi. Pengolahan data dilakukan dengan menarik simpulan secara induktif.

\section{HASIL DAN PEMBAHASAN}

\section{Peranan Guru Dalam Pembinaan Sikap dan Kedisiplinan Siswa}

Salah satu tugas yang harus dilaksanakan oleh guru di sekolah ialah memberikan pelayanan kepada para siswa agar mereka menjadi siswa atau anak didik yang selaras dengan tujuan sekolah itu. Melalui bidang pendidikan, guru mempengaruhi berbagai aspek kehidupan, baik social, budaya, maupun ekonomi. Dalam keseluruhan proses pendidikan, guru merupakan factor utama yang bertugas sebagai pendidik. Guru memegang berbagai jenis peranan yang mau tidak mau, harus dilaksanakannya sebagai seorang guru. Guru harus bertanggung jawab atas hasil kegiatan belajar anak melalui interaksi belajar mengajar. Guru merupakan factor yang mempengaruhi berhasil tidaknya proses belajar, dan karenanya guru harus menguasai prinsipprinsip belajar di samping menguasai materi yang akan diajarkan. Dengan kata lain, guru harus mampu menciptakan suatu situasi kondisi belajar yang sebaik-baiknya. Khususnya dalam pendidikan Islam seorang guru harus memiliki keteladanan yang baik yang patut untuk ditiru peserta didik khususnya dalam menanamkan nilai-nilai agamis.

Mengingat begitu penting guru dalam pendidikan, maka guru dituntut untuk memiliki kriteria-kriteria tersebut. Guru merupakan figur atau panutan peserta didik dalam mengambil semua nilai dan pemikiran tanpa memilih antara yang baik dengan yang buruk. Peserta didik memandang bahwa guru adalah satusatunya sosok yang sangat disanjung. Maka didikan dari guru berpengaruh besar dalam membentuk kepribadian dan pemikiran peserta didik.

Dari wawancara peneliti dapat diketahui bahwa 
"keteladanan guru, sifat, kepribadian, perilaku dan tutur kata guru semuanya dilihat dan diamati oleh siswa. Inilah yang semestinya diketahui oleh guru PPKn dalam mengajar. Dari proses pengamatan indera inilah siswa dapat meniru dan mencontoh apa yang dikatakan dan dilakukan oleh guru".

Bahwa pengaruh keteladanan guru sangat efektif dalam membentuk kepribadian siswa. Ini dapat dilihat dari jawaban adik Nana Lutfiana siswa kelas yang menyatakan bahwa dia selalu teringat oleh sikap dan perilaku gurunya yang halus bicaranya dan ramah tamah terhadap siswa lain. Selain itu, Nana Lutfiana juga terinspirasi oleh gurunya dalam menjalankan sembahyang.

\section{Bentuk-Bentuk Pembinaan Disiplin Siswa}

Disiplin bukanlah sesuatu yang dibawa sejak lahir. Perkembangannya pada anak sangat dipengaruhi oleh faktor "ajar" atau pendidikan. Displin selalu berkaitan dengan sikap, yaitu kesediaan bereaksi atau bertindak terhadap objek atau keadaan tertentu. Sikap selalu dihadapkan pada pilihan untuk menerima atau menolak, bertindak positif atau negatif. Sikap (sering disebut sikap mental) berkembang dalam proses keinginan untuk mendapat kepuasan, tetapi kenyataan menunjukkan bahwa tidak semua keinginan dapat terpenuhi, karena keinginan banyak orang beraneka ragam sehingga perlu adanya peraturan, tata tertib, nilai atau norma yang harus dipatuhi.

Agar dapat memenuhi atau menahan keinginan tersebut, individu yang bersangkutan harus dapat menahan diri, menguasai diri untuk tunduk pada peraturan dan patuh pada nilai atau norma yang berlaku. Disiplin selain berhubungan dengan penguasaan diri juga dengan rasa tanggung jawab. Orang yang disiplin cenderung patuh, mendukung dan mempertahankan tegaknya peraturan dan nilai yang berlaku. Sikap ini menunjukkan adanya rasa tanggung jawab yang dapat berkembang menjadi sikapnya dalam kehidupan seharihari.

Guru harus senantiasa menjadi teladan untuk seluruh siswanya di manapun berapada, karena para siswa tersebut akan cenderung melakukan perbuatan positif jika mereka melihat secara langsung contoh yang diberikan oleh para guru tersebut dan guru selalu memberikan contoh sikap yang baik kepada siswa, memantau kegiatan yang dilakukan oleh para siswa ketika berada di lingkungan sekolah. Pemantauan tersebut bertujuan agar para siswa dapat mematuhi peraturan sekolah, sehingga tercipta suasana yang nyaman dan proses belajar mengajar berjalan dengan baik.

Berkaitan dengan tindakan guru untuk memberikan sanksi kepada siswa-siswi yang melanggar aturan di lingkungan sekolah, para guru menyatakan bahwa jika pelanggaran disiplin ringan maka guru langsung memberikan teguran lisan, kalau pelanggaran disiplinnya berat maka guru melaporkan kepada guru BP, apabila pelanggaran sudah dilakukan berulang kali, maka guru mengadukan kepada wali kelas, wali kelas mengundang orang tua siswa untuk membicarakan dengan pihak sekolah pola pembinaan disiplin anak di lingkungan rumah, masyarakat, dan sekolah.guru berkewajiban menasehati siswa yang melanggar peraturan, melaporkan kepada guru BP dan Wali Kelas jika sering melanggar, melaporkan kepada orang tua siswa melalui wali kelas jika siswa melakukan pelanggaran disiplin berat. Berkaitan dengan tindakan guru untuk memberikan pengertian tentang pentingnya kedisiplinan di lingkungan sekolah, guru berpendapat bahwa kedisiplinan di lingkungan sekolah itu sangaat penting ditegakkan karena disiplin memberikan efek positif terhadap sistem pembelajaran di lingkungan sekolah. Kepala sekolah dan guru menyampaikan pentingnya disiplin siswa pada saat apel, upacara bendera, serta di sela-sela proses pembelajaran di kelas, guru harus lebih memberikan pengarahan lebih lanjut tentang pentingnya kedisiplinan siswa agar seluru siswa di SMP Negeri 2 Donggo bisa lebih taat lagi terhadap peraturan-peraturan sekolah.

\section{Faktor Pendukung dan Penghambat Dalam Keteladanan dan Kedisiplinan siswa}

Proses kegiatan pembelajaran, seorang guru mempunyai tugas menciptakan kondisi yang memungkinkan proses belajar mengajar berlangsung secara optimal. Pembelajaran akan berlangsung efektif jika pembelajaran ditekankan kepada keaktifan siswa dalam belajar dari pada faktor guru dalam mengajar. Proses pembelajaran menuntut peserta didik mengalami keterlibatan intelektual-emosional, di samping keterlibatan fisiknya. Keaktifan tersebut dapat berbentuk pemusatan perhatian apa yang dijelaskan oleh guru yang disertai penerapan praktis terhadap materi yang diajarkan.

Dipandang dari segi siswa, maka pembelajaran yang efektif adalah proses kegiatan yang dilakukan siswa dalam rangka belajar, yang dapat membangkitkan motivasi belajar, sedangkan jika dipandang dari sudut guru, maka pembelajaran yang efektif adalah pembelajaran yang dirancang sedemikian rupa sehingga proses pembelajaran yang dilaksanakan dapat menciptakan aktifitas/perilaku siswa terhadap apa yang menjadi harapan guru.

Terkait dengan pembentukan kepribadian siswa, suasana pembelajaran yang kondusif sangat membantu guru dalam memberikan keteladanan kepada siswa. Guru akan mudah memberikan nasehat, contoh sikap dan perilaku yang baik sehingga siswa akan mudah menangkap pesan-pesan moral yang terkandung dalam setiap ucapan, sikap dan perilaku guru. Suasana yang sangat efektif bagi guru PPKn dalam menerapkan nilainilai keagamaan kepada siswa adalah ketika pelaksanaan shalat Dhuhur secara berjamaah. Dari kegiatan tersebut, 
guru PPKn dapat memberikan contoh perilaku keteladanan yang dapat dilihat secara langsung oleh siswa.

Sarana prasarana/fasilitas pembelajaran yang kurang mendukung/minim merupakan salah satu penyebab ketidakefektifan kegiatan pembelajaran di kelas. Seorang guru akan mengalami kesulitan apabila dalam menjelaskan suatu materi tidak dibantu dengan alat peraga/media pembelajaran yang mendukung. Apalagi dalam mengajar materi praktik keagamaan. Guru juga akan mengalami kesulitan manakala dihadapkan pada materi yang membutuhkan keterkaitan antara konsep-konsep.

Berdasarkan observasi peneliti di Di SMP Negeri 2 Donggo kegiatan pembelajaran PPKn sangat ditunjang oleh sarana dan prasarana pembelajaran yang memadai. di Di SMP Negeri 2 Donggo secara umum sarana pembelajaran dapat dibagi menjadi dua bentuk, yaitu sarana pembelajaran visual dan audio visual. Sarana pembelajaran (visual dan audio visual) sangat membantu guru PPKn dalam menjelaskan materi khususnya yang berkaitan dengan rasa tanggug jawab.

Orang tua adalah pendidik pertama yang dikenal oleh anak, sebelum anak itu mengenal lingkungan luar. Kedudukan orang tua sebagai pendidik, pembimbing dan pembina anak yang pertama, akan sangat mewarnai dan menentukan pembentukan sikap serta kesiapan anak dalam melaksanakan ajaran-ajaran Islam. Jadi orang tua mempunyai kesempatan yang pertama untuk mengisi memori anak dengan hal-hal yang baik. Dan salah satu bentuk pengajaran yang dapat dilakukan oleh orang tua dalam membentuk kepribadian anak adalah dengan memberikan keteladanan.

Yang termasuk dalam kategori karakter positif antara lain; penurut, pendiam, pemalu, dan sabar. Sedangkan karakter yang negatif antara lain; kasar, pemalas, hiperaktif, dan acuh tak acuh. Kasar bukan berarti selalu memukul temannya-temannya, pemalas bukan berarti sering tidak masuk kelas, hiperaktif bukan berarti sok tahu, dan acuh tak acuh bukannya dia sering merenung dan menyendiri, tetapi sifat tersebut melekat pada diri siswa yang memiliki kecenderungan positif. Karakter tersebut tentu membuat guru PPKn harus bekerja keras memutar otak dan berpikir bagaimana cara membentuk kepribadian siswa yang multikarakter. Karakter merupakan bawaan seseorang yang dibawa sejak lahir. Karakter yang tergolong negatif itu wajar, begitu juga dengan karakter yang positif, semuanya tidak ada yang salah.

Siswa yang mempunyai karakter positif tidak merupakan jaminan bahwa guru akan mudah dalam membentuk kepribadian siswa. Siswa yang mempunyai karakter penurut, pendiam, pemalu dan sabar, terdapat dua asumsi bagi guru; pertama, siswa memang sudah memahami materi dengan baik dan dapat meneladani sikap serta perilaku guru. Kedua, siswa belum memahami materi dengan baik dan belum dapat meneladani sikap dan perilaku guru. Hal ini karana siswa merasa malu, minder, atau takut bertanya padahal mereka belum memahami materi. Kondisi seperti inilah yang dialami oleh guru PPKn di Di SMP Negeri 2 Donggo. Kemudian siswa yang mempunyai karakter negatif, seperti; kasar, pemalas, hiperaktif, dan acuh tak acuh tidak dapat dikatakan bahwa mereka tidak memahami materi dengan baik dan belum meneladani sikap dan perilaku gurunya. Buktinya ketika peneliti melihat siswa yang mempunyai karakter seperti ini, mereka di hadapan guru sangat sopan dan berperilaku sesuai dengan norma- norma agama. Selain itu, ketika peneliti melihat nilai ulangan beberapa siswa yang berkarakter negatif, ternyata nilai mereka juga baik. Mereka malas bisa karena sudah memahami materi dengan baik, mereka kasar karena ingin menjadi pemimpin teman-temannya, mereka hiperaktif karena ingin menunjukkan bakat-bakatnya, dan mereka acuh tak acuh karena tidak ingin mengganggu orang lain. Berbagai karakter siswa yang beragam dalam satu kelas maupun lain kelas inilah yang menjadikan guru PPKn mengalami hambatan dalam menerapkan sikap, perilaku, dan keteladanan guna membentuk kepribadian siswa.

\section{TEMUAN DAN DISKUSI}

Guru PPKn dalam menerapkan keteladanan dibarengi dengan kedisiplinan yang tinggi. Sikap disiplin dapat dilihat dengan ketepatan waktu mengajar dan dalam praktik ibadah seperti shalat Dhuhur yang dilakukan secara berjamaah bagi siswa. Hal ini dimaksudkan agar siswa akan terbiasa melakukan sesuatu tepat pada waktunya dan tidak menunda-nunda pekerjaannya. Guru PPKn juga disiplin dalam mengajar. Mereka hanya meninggalkan tugasnya (absen) ketika ada keperluan yang sangat penting. Sikap disiplin inilah yang membuat siswa menaruh rasa hormat dan simpati terhadapnya. Jadi guru sebagai actor utama dalam membina peserta didik setidak harus memberikan sikap keteladanan yang baik seperti pakaian, tutur kata, bersilaturahmi, bergaul denga siswa maupun teman sejawat, berprestasi hal itu dilakukan akan dilihat dan ditiru oleh peserta didik lainnya maupun guru-guru, maupun masyarakat lainnya.

Hal tersebut sejalan dengan penelitian yang menjelaskan bahwa Pendidik merupakan figur utama dalam lingkungan pendidikan yang utama dijadikan teladan bagi peserta didik. Pendidik bukan hanya dilingkungan sekolah namun juga dilingkungan keluarga dan masyarakat seperti guru, orang tua dan tokoh masyarakat. Untuk memperlancar pencapaian tujuan pendidikan karakter maka harus dibentuk teladan dalam lingkungan pembentuk karakter sebagai bagian dari komponen penguat karakter peserta didik. Maka dari itu, pendidikan karakter di sekolah harus menyediakan figur teladan untuk contoh bagi peserta didik. Dengan guru 
memiliki nilai, sikap, dan perilaku yang dapat diteladani maka peserta didik bukan hanya memiliki pengertian tentang nilai namun juga pemahaman dan keyakinan akan nilai yang ingin dibentuk karena adanya figur teladan[16].

Guru harus senantiasa menjadi teladan untuk seluruh siswanya di manapun berapada, karena para siswa tersebut akan cenderung melakukan perbuatan positif jika mereka melihat secara langsung contoh yang diberikan oleh para guru tersebut dan guru selalu memberikan contoh sikap yang baik kepada siswa, memantau kegiatan yang dilakukan oleh para siswa ketika berada di lingkungan sekolah. Pemantauan tersebut bertujuan agar para siswa dapat mematuhi peraturan sekolah, sehingga tercipta suasana yang nyaman dan proses belajar mengajar berjalan dengan baik.

Fasilitas pendukung untuk mendidik siswa berupa sarana prasarana/fasilitas pembelajaran yang memadai merupakan salah satu indicator keberhasilan pendidikan di sekolah. Seorang guru akan mengalami kesulitan apabila dalam menjelaskan suatu materi tidak dibantu dengan alat peraga/media pembelajaran yang mendukung. Apalagi dalam mengajar materi praktik keagamaan. Guru juga akan mengalami kesulitan manakala dihadapkan pada materi yang membutuhkan keterkaitan antara konsep-konsep PKn.

\section{E. SIMPULAN DAN SARAN}

Peranan guru dalam meningkatkan kedisiplinan siswa menunjukkan, 1) Peranan Guru dalam pembinaan disiplin siswa SMP Negeri 2 Donggo adalah: meningkatkan ketaqwaan siswa terhadap Tuhan Yang Maha Esa; mengadakan pembinaan untuk mempertinggi budi pekerti dan kepribadian siswa; membimbing tingkah laku siswa sehari-hari di sekolah; meningkatkan kerajinan, ketekunan, dan kesantunan; memberikan tindakan terhadap siswa yang melanggar; memberikan peringatan secara lisan, dan memberikan teladan yang baik kepada siswa; 2) Bentuk

pembinaan disiplin siswa yang dilakukan oleh Guru adalah: menunjukan/memberi contoh sikap disiplin; menegur siswa yang melanggar secara lisan; menyampaikan manfaat dari berdisiplin; memberikan sanksi terhadap siswa yang melanggar baik sanksi ringan maupun sanksi berat; mengadukan siswa yang melanggar kepada wali kelas, guru BP, kepala sekolah, dan orang tua siswa; 3) Faktor pendukung dan penghambat dalam peran keteladanan dan kedisiplinan guru PPKn siswa kelas VII di SMPN 2 Donggo adalah: suasana lingkungan belajar yang kondusif/nyaman, sarana pembelajaran yang memadai/ menunjang, dan peran serta orang tua dalam pendidikan anak. Kemudian faktor penghambatnya adalah minimnya waktu mengajar/jumlah tatap muka dengan siswa dan perbedaan karakter siswa.
Dengan demikian menyarankan kepada guru bahwa guru perlu meningkatkan pembinaan disiplin terhadap siswa SMP Negeri 2 Donggo. Bentuk pembinaan disiplin seperti; menunjukan sikap disiplin; menegur siswa yang melanggar secara lisan; menyampaikan manfaat dari berdisiplin; sanksi terhadap siswa yang melanggar baik sanksi ringan maupun sanksi berat; mengadukan siswa yang melanggar kepada wali kelas, guru BP, kepala sekolah, dan orang tua siswa harus dikembangkan dan lebih diintensifkan lagi.

\section{UCAPAN TERIMA KASIH}

Penulis mengucapkan terima kasih kepada Universitas Muhammadiyah Mataram yang senantiasa memberikan dukunga materi dan moral dan masukan kepada penulis sehingga artikel ilimiah ini selesai dengan baik.

\section{DAFTAR RUJUKAN}

[1] B. Maunah, "Implementasi pendidikan karakter dalam pembentukan kepribadian holistik siswa," J. Pendidik. Karakter, no. 1, 2015.

[2] S. Rijal and S. Bachtiar, "Hubungan antara Sikap, Kemandirian Belajar, dan Gaya Belajar dengan Hasil Belajar Kognitif Siswa,” J. Bioedukatika, vol. 3, no. 2, pp. 15-20, 2015.

[3] A. Sudrajat, "Perkembangan kognitif," Jakarta Bumi Aksara, 2008.

[4] F. J. Fiana, D. Daharnis, and M. Ridha, "Disiplin siswa di sekolah dan implikasinya dalam pelayanan bimbingan dan konseling," Konselor, vol. 2, no. 3, 2013.

[5] M. Y. Bachtiar, "Pendidik dan Tenaga Kependidikan," Publ. Pendidik., vol. 6, no. 3, 2016.

[6] F. Y. Fauzi, I. Arianto, and E. Solihatin, "Peran Guru Pendidikan Pancasila Dan Kewarganegaraan Dalam Upaya Pembentukan Karakter Peserta Didik,” J. PPKN UNJ Online,(Online), vol. 1, no. 2, 2013.

[7] Z. Z. Mutaqin, "Indonesian Customary Law and European Colonialism: A Comparative $\backslash$ Analysis on Adat Law," J. East Asia Int. Law, vol. 4, no. 2, pp. 351-376, 2011.

[8] M. M. P. M. K. Batulayar and K. L. Barat, "Pemberdayaan Ekonomi Umat Islam," J. Penelit. Keislam., vol. 4, no. 1, pp. 85-98, 2007.

[9] D. Mutmainah and K. Kamaluddin, "Peran Guru Pendidikan Pancasila Dan Kewarganegaraan Dalam Membentuk Sikap Dan Kepribadian Siswa," Civ. Pendidikan-Penelitian-Pengabdian Pendidik. Pancasila dan Kewarganegaraan, vol. 6, no. 2, pp. 44-53, 2019.

[10] Sugiyono, Metode Penelitian Pendidikan:(Pendekatan Kuantitatif, Kualitatif dan $R \& D$ ). Alfabeta, 2014.

[11] Sugiyono, "Memahami Penelitian Kualitatif," Bandung Alf., 2005.

[12] B. D. Suwandi and M. Si, "Memahami Penelitian Kualitatif Jakarta: PT," Reneka Cipta, 2008.

[13] A. Suharsimi, "Prosedur penelitian suatu pendekatan praktik," Jakarta: Rineka Cipta, 2006. 
26 CIVICUS : Pendidikan-Penelitian-Pengabdian Pendidikan Pancasila dan Kewarganegaraan | Vol. 7, No. 2, September 2019, hal $19-26$

[14] Sugiyono, "Metode Penelitian kuantitatif kualitatif dan R dan D," Alf. Bandung, 2010.

[15] L. J. Moleong, Metode Penelitian Kualitatif. Bandung: Remaja Rosdakarya, 2007.

[16] N. W. Wardhani and M. Wahono, "Keteladanan Guru Sebagai Penguat Proses Pendidikan Karakter," Untirta Civ. Educ. J., vol. 2, no. 1, 2017. 